\title{
Comparative Analysis of Microwave based Joining/Welding of SS304- SS304 using Different Interfacing Materials
}

\author{
Lucky Bagha $^{1}$, Shankar Shegal ${ }^{1}$ and Amit Thakur ${ }^{2}$ \\ ${ }^{1}$ UIET, Panjab University, Chandigarh, India
}

\begin{abstract}
In recent years, researchers have developed methods for joining bulk metals like aluminium, stainless steel, mild steel, cast iron etc. through microwave radiations. The present work is based on the joining of stainless steel-304 with two different interface materials i.e. Nickel based EWAC powder and $99.9 \%$ pure Nickel based powder. The obtained samples were characterized by XRD, SEM and Rockwell hardness test on HRC scale. The experimental results show that the Nickel based EWAC powder is better in terms of weldability than $99.9 \%$ pure Nickel based powder.
\end{abstract}

\section{Introduction}

Welding is an essential process used for joining basic parts. It is almost used in every industries, railway, ship buildings, cars, aeroplane, civil construction etc. It is likewise broadly utilized for the manufacturing and repair of machine tools, farm equipment. Therefore the cost and quality of a finished product depends upon the quality of welding joints and its structure. Microwave joining of materials is a new non-conventional technique emerged in the recent years. The unique characteristics of microwave radiations like volumetric heating, less power utilization, eco-friendly with environment, highly quality products etc. are attracting numbers of researches in this field. This technique in not fully developed as compared to other joining techniques but results of this technique are relatively better in terms of hardness, HAZ and tensile strength. Many materials which are extensively used in industries like aluminium, stainless steel, cast iron, etc [1-8]. has been joined by microwave joining process. In case of stainless steel, the interface materials used for microwave joining includes nickel based powder or nickel based EWAC powder. These two materials are in powder form made from same parent material i.e. nickel but show different results in microwave joining. In this research, work-pieces of stainless steel 304 are joined by microwave joining with the help of both nickel based EWAC powder $(50 \mu$ in size) and nickel based powder $(50 \mu$ in size $)$ as interface material. Microwave heating is a procedure which utilizes electromagnetic vitality as a part of the frequency scope of 3 to $300 \mathrm{MHz}$ 's. In microwave heating the material is subjected to an electromagnetic waves that oscillates the molecules of material, there by producing heat. Microwaves are directly absorbed by the material in this manner thereby causing volumetric heating [9].

\subsection{Microwave Joining}

In microwave joining process domestic and industrial microwaves are used for bulk material joining. These domestic and industrial microwaves works on stranded frequency $2.45 \mathrm{GHz}$.

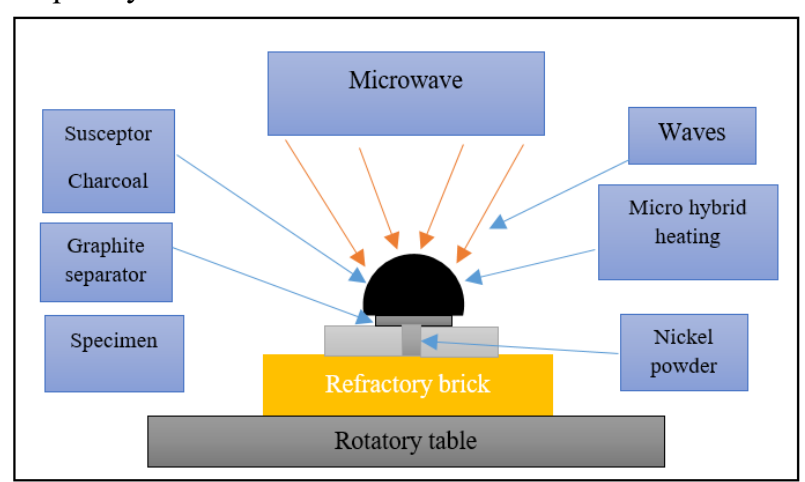

Figure 1. A schematic microwave hybrid heating processing.

Refractory brick with cavity is used to hold the work piece. Epoxy resin blumer and bisphenol-A are used to hold the interface powder [10]. Charcoal powder are used as a susceptor which suscepts the microwave radiations and concentrate them at the interface of the joint. Graphite sheet is used as a separator to separate the interface powder and susceptor powder as show in Figure 1. Bansal et al.[1] studied joint fabrication of mild steelmild steel through microwave hybrid heating in domestic 900 watt microwave. The gap was filled with an interfacing slurry of nickel based powder and epoxy resin bisphenol-A and blumer 1450XX. The joint was

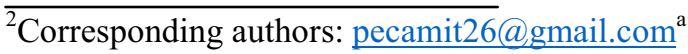


characterized using XRD, EDS, SEM, Rockwell hardness etc. Gupta et al.[3] investigated butt joint of tungsten carbide bearing alloy through microwave joining. Mild steel and stainless steel were joined by used of nickel based EWAC powder. Gupta and Kumar[2] worked on welding of SS420 with SS420 used nickel based EWAC powder as an interface material. Slurry is made by $95 \%$ nickel based powder and 5\% blumer 1450XX. The joint was characterized by XRD, SEM, micro tensile tester etc. Badiger et al.[11] worked on joining the Inconel-625 alloy through microwave hybrid heating in domestic 900 watt microwave using Nickel based powder as an interface material. The experiments were carried out in domestic microwave and characterized by XRD, SEM, and UTM etc. Bansal et al.[12] investigate on Inconel 718 structure - properties in microwave joining. The butt joined Inconel 718 plates were joined by the microwave hybrid heating technique. Inconel 718 powder as a filler material was used for microwave welding. Singh et al. [7] worked on joining aluminium-aluminium through microwave hybrid heating. Aluminium powder was used as an interface material. $\mathrm{SiC}$ powder is used as a susceptor.

\section{Experiment procedures}

\subsection{Microwave joining using EWAC}

In the present study micro hybrid heating is used for joining of SS304-SS304 bits. A Nickel based EWAC powder of particle size $50 \mu$ has been used as an interface material. The detail study regarding joining of bulk material with the help of micro hybrid heating has already reported in form of patent [4]. The SS304 bits were placed in the butt configuration with the gap of approximate $0.5 \mathrm{~mm}$. The gap was filled with interface slurry consist of $95 \%$ nickel based EWAC powder and $5 \%$ Epoxy resin blumer 1450XX. The configuration was exposed to microwave radiation for $420 \mathrm{sec}$ at $2.45 \mathrm{GHz}$ and $800 \mathrm{Watt}$. Table 1 is representing experimental results for experiments carried out on SS304 as work piece with Nickel based EWAC powder.

Table 1. Experimental results for SS304 with Nickel based EWAC powder as interface material.

\begin{tabular}{|c|c|c|c|}
\hline $\begin{array}{c}\text { Exp. } \\
\text { no. }\end{array}$ & $\begin{array}{c}\text { Interface } \\
\text { powder }\end{array}$ & $\begin{array}{c}\text { Exposure } \\
\text { time (s) }\end{array}$ & Result \\
\hline 1 & $\begin{array}{c}\text { Ni based } \\
\text { EWAC } \\
\text { powder }\end{array}$ & 360 & $\begin{array}{c}\text { Red hot and } \\
\text { not joined }\end{array}$ \\
\hline 2 & $\begin{array}{c}\text { Ni based } \\
\text { EWAC } \\
\text { powder }\end{array}$ & 420 & $\begin{array}{c}\text { Red hot and } \\
\text { joined }\end{array}$ \\
\hline
\end{tabular}

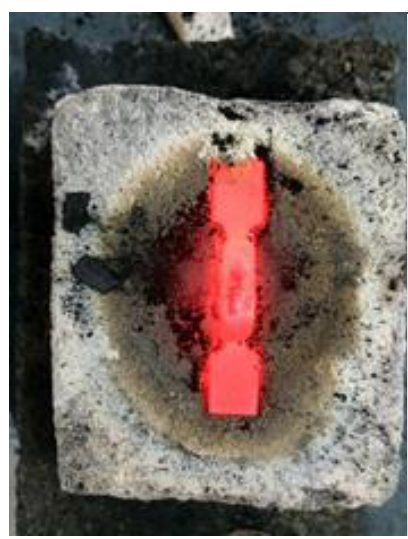

(a)

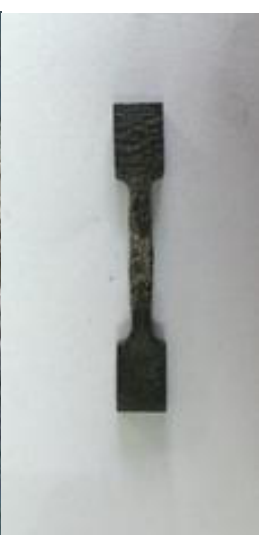

(b)
Figure 2. (a) Red hot bits placed in the cavity made in refractory brick. (b) Final joined work piece.

\subsection{Microwave joining using $99.9 \%$ Pure Nickel Based Powder}

In this experiment, $99.9 \%$ pure nickel based powder of particle size $50 \mu$ has been used as an interface material with the timing of $390 \mathrm{sec}$ at $2.45 \mathrm{GHz}$ and $800 \mathrm{Watt}$. Table 2 is representing experimental results for experiments carried out on SS304 as work piece with 99.9\% pure Nickel based powder.

Table 2. Experimental results using Nickel based powder as interface material.

\begin{tabular}{|c|c|c|c|}
\hline $\begin{array}{c}\text { Exp. } \\
\text { no. }\end{array}$ & $\begin{array}{c}\text { Interface } \\
\text { powder }\end{array}$ & $\begin{array}{c}\text { Exposure } \\
\text { time (s) }\end{array}$ & Result \\
\hline 1 & $\begin{array}{c}99.9 \% \text { pure } \\
\text { Ni based } \\
\text { powder }\end{array}$ & 450 & $\begin{array}{c}\text { Red hot, } \\
\text { Fusion and } \\
\text { not joined }\end{array}$ \\
\hline 2 & $\begin{array}{c}99.9 \% \text { pure } \\
\text { Ni based } \\
\text { powder }\end{array}$ & 420 & $\begin{array}{c}\text { Red hot, } \\
\text { Fusion and } \\
\text { not joined }\end{array}$ \\
\hline 3 & $\begin{array}{c}99.9 \% \text { pure } \\
\text { Ni based } \\
\text { powder }\end{array}$ & 360 & $\begin{array}{c}\text { Red hot, } \\
\text { Fusion and } \\
\text { joined }\end{array}$ \\
\hline
\end{tabular}

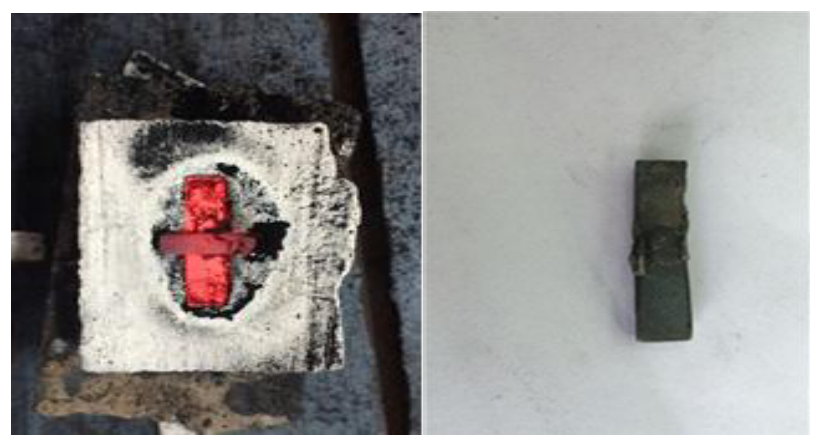

(a)

(b)

Figure 3. (a) Red hot bits placed in the cavity made in refractory brick. (b) Final joined work piece. 


\subsection{Characterization of the joints}

The joints were characterized by Energy dispersive spectroscopy (EDS), Scanning electron microscope (SEM) and Rockwell hardness test on C-scale.

\section{Results and discussion}

The results of various characterizations are discussed with suitable illustrations in the following sections.

\subsection{Energy dispersive spectroscopy}

\subsubsection{EDS result for EWAC based joining}

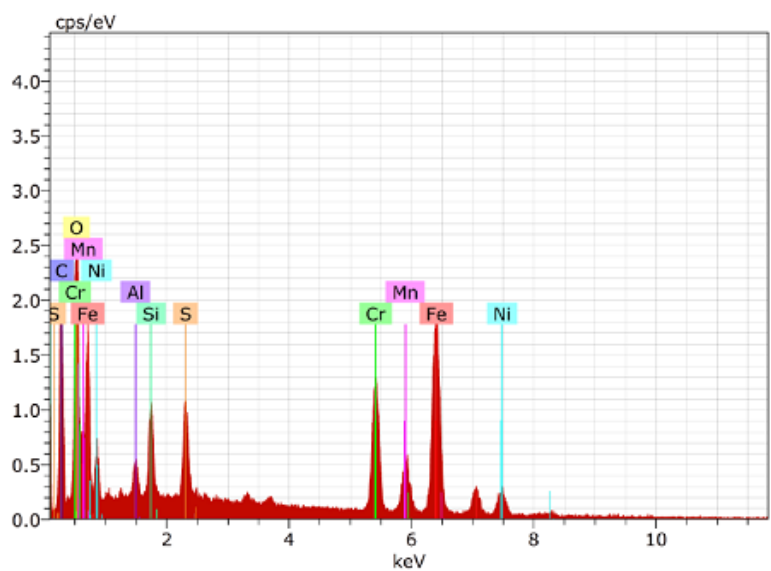

Figure 4. EDS results of Nickel based EWAC powder.

It is found from the EDS analysis in the joint region of the microstructure, the cells are of iron mainly $(\mathrm{Fe})$, chromium $(\mathrm{Cr})$, carbon(c), Nickel $(\mathrm{Ni})$ and manganese (Mn). The presence of carbides (chromium and iron) was at the grain boundaries. This is due to the precipitation of carbides near the grain boundaries owing to the difference in solidification time[4]. The sample has been scanned with scanning pulse th. $2.80 \mathrm{kcps}$ and $15.0 \mathrm{kv}$ of High voltage.

\subsubsection{EDS result for pure Nickel powder based joining}

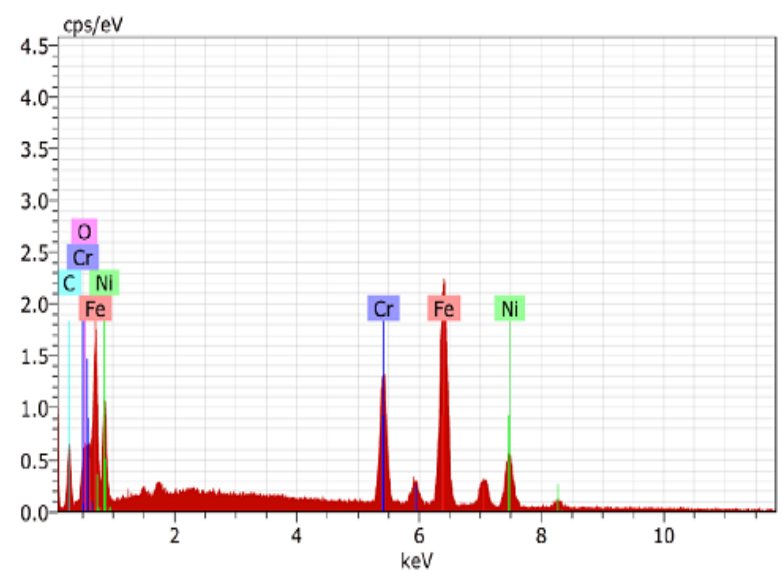

Figure 5. EDS results of Nickel based powder
It is found from the EDS analysis in the joint region of the microstructure, the cells are mainly of iron $(\mathrm{Fe})$, chromium $(\mathrm{Cr})$, Nickel (Ni), carbon (c). The sample has been scanned with scanning pulse Th. $1.73 \mathrm{kcps}$ and $15.0 \mathrm{kv}$ of High voltage.

From the EDS results, it follows:

- Carbon \% in Nickel based EWAC powder is more than the $99.9 \%$ pure Nickel based powder.

- Nickel \% in $99.9 \%$ pure Nickel based powder is more than the Nickel based EWAC powder.

\subsection{Scanning electron microscope (SEM)}

\subsubsection{SEM result for EWAC based joining}

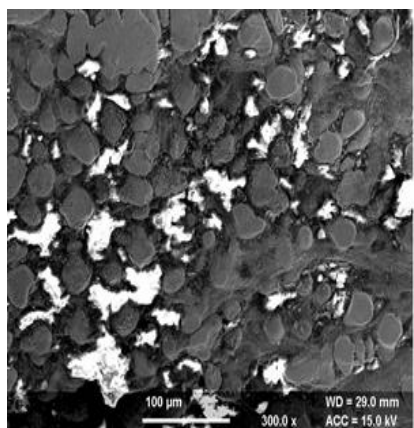

(a)

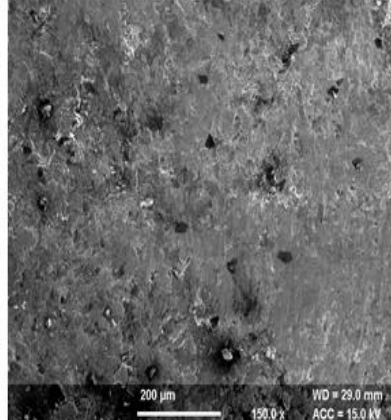

(b)
Figure 6. (a) SEM image of Nickel based EWAC powder bead. (b) SEM image of joined based metal and bead

In Figure (b), there is no Heat affected zone (HAZ) around the joint and there is a perfect joining of the bead and based material.

\subsubsection{SEM result for pure Nickel powder based} joining

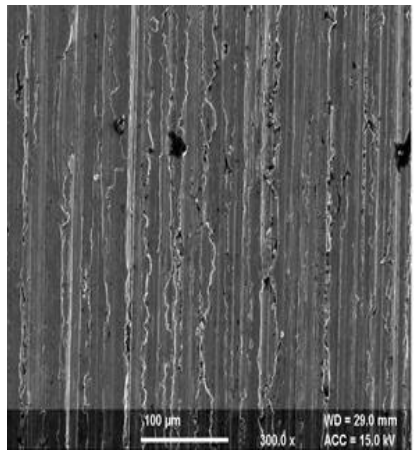

(a)

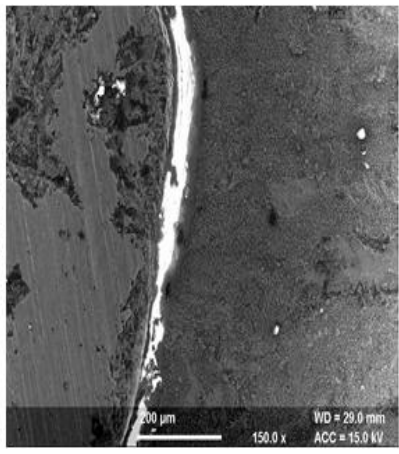

(b)
Figure 7. (a) SEM image of $99.9 \%$ pure Nickel based powder bead. (b) SEM image of joined based metal and bead 
In Figure (b), there is Heat affected zone (HAZ) around the joint and joining of bead and based material is not perfect as compare to EWAC powder.

\subsection{Rockwell hardness test and visual inspection}

Rockwell hardness test is done on the beads of both the joints to characterize the hardness of the joint on Rockwell C-scale.

Table 3. The hardness of work piece is tested by three different experiments

\begin{tabular}{|c|c|c|c|c|}
\hline Exp. & $\begin{array}{c}\text { HRC- } \\
\text { Exp. 1 }\end{array}$ & $\begin{array}{c}\text { HRC- } \\
\text { Exp. 2 }\end{array}$ & $\begin{array}{c}\text { HRC- } \\
\text { Exp. 3 }\end{array}$ & $\begin{array}{c}\text { Average } \\
\text { HRC }\end{array}$ \\
\hline $\begin{array}{c}\text { With } \\
\text { Nickel } \\
\text { EWAC } \\
\text { powder }\end{array}$ & 22 & 30 & 33 & 30 \\
\hline $\begin{array}{c}\text { With } \\
\text { 99.9\% } \\
\text { Nickel } \\
\text { powder }\end{array}$ & 37 & 46 & 45 & 42.67 \\
\hline
\end{tabular}

From the above table 3 it is clear that the hardness on the HRC scale $99.9 \%$ pure Ni based powder joint hardness is higher than the Ni based EWAC powder. Both work pieces were visually inspected and it was found that surface finish in Nickel based EWAC powder was better than $99.9 \%$ pure nickel based powder.

\section{Conclusion}

- The weldability of Nickel based EWAC powder is higher than the $99.9 \%$ pure nickel based powder.

- The percentage of carbon is less in $99 \%$ pure Nickel based joint in comparison with Nickel based EWAC powder. This helps in reducing the porosity in $99.9 \%$ pure Nickel based joint compared to EWAC based joint.

- Rockwell hardness on HRC-scale for 99\% pure Nickel based powder is higher than then EWAC powder

- Surface finish is better in Nickel based powder EWAC powder and bead size of joint is negligible as compared to $99.9 \%$ pure Nickel based powder joint.

\section{References}

1. A. Bansal, A. K. Sharma, and S. Das, "Metallurgical and mechanical characterization of mild steel-mild steel joint formed by microwave hybrid heating process," Sadhana - Acad. Proc. Eng. Sci., vol. 38, no. 4, pp. (679-686), 2013.

2. P. Gupta and S. Kumar, "Investigation of Stainless Steel Joint Fabricated Through Microwave Energy," Mater. Manuf. Process., vol. 29, no. July, pp. (910915), 2014.

3. P. Gupta, S. Kumar, and A. Kumar, "Study of Joint Formed by Tungsten Carbide Bearing Alloy through Microwave Welding," Mater. Manuf. Process., vol. 28, no. 5, pp. (601-604), 2013.

4. A. Kumar, "Microwave Joining of Stainless Steel and Their charactrizationS.," Thapar university, 2015.

5. A. Pathania, S. Singh, D. Gupta, and V. Jain, "Development and analysis of tribological behavior of microwave processed EWAC $+20 \% \mathrm{WC} 10 \mathrm{Co} 2 \mathrm{Ni}$ composite cladding on mild steel substrate," $J$. Manuf. Process., vol. 20, pp. (79-87), 2015.

6. S. Saxena, S. Bansal, R. Deo, and S. Khan, "Joining of Bulk Metallic Pipes by Microwave Hybrid Heating Processunder Parametrical Regulations," IOSR J. Mech. Civ. Eng., vol. 11, no. 6, pp. (62-69), 2014.

7. S. Singh, N. M. Suri, and R. M. Belokar, "Characterization of Joint Developed by Fusion of Aluminum Metal Powder through Microwave Hybrid Heating," Mater. Today Proc., vol. 2, no. 4 5, pp. (1340-1346), 2015.

8. M. S. Srinath, P. S. Murthy, A. K. Sharma, P. Kumar, and M. V Kartikeyan, "Simulation and analysis of microwave heating while joining bulk copper," Int. J. Eng. Sci. Technol., vol. 4, no. 2, pp. (152-158), 2012.

9. R. R. Mishra and A. K. Sharma, "Microwavematerial interaction phenomena: Heating mechanisms, challenges and opportunities in material processing," Compos. Part A Appl. Sci. Manuf., vol. 81, pp. (78-97), 2016.

10. M. Kwak, P. Robinson, A. Bismarck, and R. Wise, "Microwave curing of carbon-epoxy composites: Penetration depth and material characterisation," Compos. Part A Appl. Sci. Manuf., vol. 75, pp. (1827), 2015.

11. R. I. Badiger, S. Narendranath, and M. S. Srinath, "Joining of Inconel-625 alloy through microwave hybrid heating and its characterization," J. Manuf. Process., vol. 18, no. January, pp. (117-123), 2015.

12. A. Bansal, A. K. Sharma, P. Kumar, and S. Das, "Structure-Property Correlations in Microwave Joining of Inconel 718," Jom, vol. 67, no. 9, pp. (2087-2098), 2015. 